\title{
Implementasi Program Bermain Sambil Belajar Budaya Untuk Siswa Tunagrahita Di SDLBN Kecamatan Balikpapan Selatan Sebagai Alternatif Pengenalan Kearifan Lokal Dan Budaya Indonesia Sejak Usia Dini
}

\author{
Muhammad Kamaluddin ${ }^{1}$, Umi Sholikah ${ }^{2}$, Rizjal Wahyu ${ }^{3}$, Nur Laily Rahmania ${ }^{4}$, \\ Hariandy Firdauz ${ }^{5}$, Alnovia Suryaningsih ${ }^{6}$ \\ 1,3,4,5,6 Program Studi Teknik Sipil, Jurusan Teknik Sipil \& Perencanaan, Institut Teknologi Kalimantan \\ ${ }^{2}$ Jurusan Teknik Lingkungan, Institut Teknologi Kalimantan \\ ${ }^{1}$ mkaamall1@gmail.com
}

\begin{abstract}
ABSTRAK
Tunagrahita merupakan anak dengan kebutuhan khusus yang memiliki IQ antara 50-70. Kelainan penyerta anak tunagrahita seperti spastik, autism, hiperaktif, atau kesulitan belajar. Pengenalan budaya sejak dini juga memiliki urgensi yang sangat besar terutama bagi anak tunagrahita. Hal ini bertujuan untuk mengenalkan identitas bangsa dan kearifan lokal yang telah diwariskan sejak lama. Oleh karena itu, dilaksanakan program bermain sambil balajar budaya di SDLBN Kecamatan Balikpapan Selatan ini dengan metode yang terdiri dari pengenalan program, pelaksanaan program, serta evaluasi kegiatan. Saat kegiatan berlangsung, tunagrahita sangat hiperaktif dan memiliki daya tangkap yang kurang. Namun, melalui penerapan metode pembelajaran sambil bermain tim volunteer mampu membuat siswa-siswi yang mengikuti kegiatan ini semakin semangat dan berani menunjukkan kemampuan mereka. Pada kegiatan akhir yaitu simulasi, orang tua diajak untuk ikut serta sehingga terjalin kedekatan antar siswa tunagrahita dengan orangtuanya. Program ini dapat menjadi salah yang satu kegiatan dapat diterapkan pada sekolah-sekolah lainnya karena penerapan metode pembelajaran yang komunikatif dan menyenangkan untuk siswa tunagrahita dalam mengenalkan kearifan lokal dan budaya Indonesia sejak usia dini.
\end{abstract}

Kata kunci: budaya, kearifan, pengenalan, tunagrahita

\section{PENDAHULUAN}

Tunagrahita merupakan anak dengan berkebutuhan khusus yang memiliki intelejensi (IQ) di bawah rata-rata yaitu berkisar antara 50-70. Biasanya anak tunagrahita mempunyai kelainan penyerta, seperti spastik, autism, hiperaktif, atau kesulitan belajar. Oleh karena itu, perkembangan kognisi dan sosial meliputi perkembangan pada tingkat sensorimotor, akademik, kemampuan berbahasa, keterampilan mengurus diri sendiri, pemahaman terhadap konsep diri, kemampuan berinteraksi sosial dan menumbuhkan rasa kreativitas sangat dibutuhkan seorang anak penyandang tunagrahita. Adapun salah satu cara yang dapat ditempuh dalam meningkatkan sistem motorik anak tunagrahita yaitu melalui permainan maupun kegiatan lain yang dapat memacu sistem gerak dan kepekaannya dalam berfikir (Fithriyani, 2015). Hal diperkuat melalui kajian Odom dan Wolery (2003) menyebutkan bahwa anak usia dini dengan disabilitas termasuk tunagrahita akan belajar banyak melalui bermain dan mengobservasi lingkungan mereka.
Telah banyak kajian ataupun penelitian yang menunjukkan bahwa bermain memiliki peran yang penting dalam mengembangkan kemampuan bagi seorang anak dengan penyandang status tunagrahita, termasuk di dalammnya adalah permainan tradisional (Oedjoe, 2016). Di sisi lain pengenalan budaya dan kearifan lokal Indoneisa kepada siswa tunagrahita juga memiliki urgensi yang tinggi, hal ini betujuan untuk mengenalkannya kepada mereka mengenai warisan yang telah ada dari nenek moyangnya dahulu seperti musik tradisional, rumah tradisional sampai permainan tradisional yang seharusnya telah di perkenalkan saat mereka menempuh jenjang pendidikan khusus. Namun, pada kenyataannya dikarenakan keterbatasan yang ada siswa tunagrahita tidak dapat menyerap materi dan ilmu budaya dan kearifan lokal tersebut di sekolahnya.

Berdasarkan latar belakang tersebut, penulis memiliki solusi alternatif pengenalan budayan dan kearifan lokal Indonesia kepada siswa tunagrahita sejak dini melalui metode bermain sambil belajar budaya dimana 
program ini sudah penulis implementasikan di SDLBN Kecamatan Balikpapan Selatan. Dalam program berisi pengembangan karakter melalui kesenian dan kreativitas dengan submateri/kategori yaitu pengenalan musik tradisional, rancang bangun rumah tradisional, dan bermain permainan tradisional yang berasal dari Indonesia, dengan memasukkan unsur belajar sambil bermain kedalamnya. Selain itu, volunteer juga menerapkan pendekatan dengan cara bercerita dan ice breaking untuk menjalin kedekatan dengan siswa di SDLBN Kecamatan Balikpapan Selatan yang menjadi target program.

\section{METODE PENELITIAN}

Pelaksanaan ini dilaksanakan selama 3

bulan di SDLBN Kecamatan Balikpapan Selatan dengan target program yaitu siswa tunagrahita dari kelas 3-5 SD. Adapaun tahapan pelaksanaan program ini yaitu:

1. Pengenalan Program

Pengenalan Program dilakukan kepada kepala sekolah dan guru-guru tunagrahita di SDLBN Kecamatan Balikpapan Selatan Program, tujuannya adalah untuk memaparkan program, pemaparan input dan output kegiatan program yang akan dilaksanakan, memperkenalkan tim volunteer (keakraban), serta memaparkan program dan juga saling berdiskusi dengan guru-guru SDLBN Kecamatan Balikapan Selatan untuk meminta masukan/saran dari dewan guru dalam upaya memilah siswa-siswi SDLBN Kecamatan Balikapan Selatan untuk bekal pembagian kelompok sesuai minat siswa/siswi ke dalam materi seni dari program Program. Selanjutnya, tim volunteer bertemu dengan para siswa SDLBN Kecamatan Balikpapan Selatan untuk memperkenalkan program ini. Hal tersebut dilakukan sebagai upaya awal untuk memperkenalkan dan mendekatkan diri dengan siswa. Pada tahap pendekatan dengan siswa, tim juga memiliki maksud dan tujuan untuk mengabdi dan memperkenalkan program ini. Pada kesempatan itu pula tim mengamati serta melihat kemampuan siswa/siswi sebagai bekal pemberian materi dan pelaksanaan program.

\section{Pelaksanaan Program}

Tahap ini merupakan tahap inti dari kegiatan training Program. Pada tahap ini terdiri dari materi, pembagian kelompok dan latihan terpadu.

a) Materi

Materi yang disampaikan yaitu dari sisi budaya dan kearifan lokal di Indonesia yakni bermusik, permainan rancang bangun bangunan tradisional dan bermain permainan tradisional. Materi bermusik terdiri atas bernyanyi lagu tradisional dan bermain alat musik tradisional, jadi tim volunteer memberikan ilmu bermusik dengan bernyanyi dan bermain alat musik bersama dengan anakanak tunagrahita di SDLBN Kecamatan Balikpapan Selatan sebagai bekal mereka untuk mengetahui musik tradisional di Indonesia. Untuk permainan rancang bangun (bangunan tradisional) tim volunteer menampilkan beberapa contoh video kreasi cara membuat dan menghias bangunan tradisional menggunakan bahan-bahan sederhana, disini tim volunteer harus benarbenar membimbing anak-anak tunagrahita namun dengan cara yang menyenangkan dan tidak membosankan bagi mereka. Yang terakhir yaitu bermain permainan tradisional, tim volunteer juga memperkenalkan kearifan lokal dengan bermain permainan tradisional baik itu yang ada di Kalimantan pada khususnya, maupun di seluruh wilayah Indonesia dengan memutarkan video mengenai beberapa contoh permainan tradisional di beberapa wilayah di Indonesia serta cara memainkannya (dalam hal ini tim volunteer harus sangat interaktif dalam berinteraksi dengan anak-anak tunagrahita agar mereka dapat menangkap materi dan tidak merasa bosan).

\section{b) Latihan Terpadu}

Setelah pemberian materi, siswa tunagrahita diberikan latihan terpadu agar kemampuan mereka dalam menguasai materi yang diberikan semakin terasah dengan baik. Dalam kegiatan ini siswa dibagi menjadi beberapa kelompok untuk memaksimalkan pengawasan dan pendampingan yang dilakukan oleh volunteer. Tahap latihan ini dirancang sebagai sarana siswa dalam mempelajari budaya dan kearifan lokal yang telah diajarkan, dengan memperaktekkannya secara langsung bersama teman-temannya untuk memupuk jiwa sosial dan rasa kepercayaan diri anak-anak tunagrahita di Kecamatan Balikpapan Selatan. Untuk bermusik tim volunteer lebih mengasah cara bernyanyi dan memainkan alat-alat musik tradisional dengan menyanyikan lagu-lagu dan memainkan alat musik yang memiliki nilai budaya dan nilai kearifan lokal masyarakat setempat yang sangat mudah dipelajari untuk anak-anak. Desain rancang bangunan pun dibuat mudah dengan mengutamakan 
pengetahuan dengan menyusun puzzle dengan gambar rumah tradisional yang ada di Indonesia menggunakan bahan-bahan sederhana. Sama halnya dengan bermusik dan permainan rancang bangun, dalam bermain permainan tradisional tim volunteer juga mengajak anak-anak tunagrahita untuk memainkannya seperti permainan ular naga.. Tujuan utama dari adanya latihan terpadu ini adalah untuk melatih jiwa mandiri, memupuk jiwa sosial dan kepercayaan diri, serta melatih sistem motorik anak-anak tunagrahita SDLBN Kecamatan Balikapan Selatan.

\section{Controlling}

Controlling pada program bertujuan untuk melihat dan mengevalusi ketika program berjalan khususnya pada saat pemberian materi dan latihan terpadu. Mekanisme controlling mencakup dua metode. Metode pertama menggunakan jurnal penilaian. Jurnal penilaian berfungsi untuk mengetahui kemampuan siswa-siswi disetiap mendapat materi. Kemudian juga dapat menjadi evaluasi bagi tim/pemateri/volunteer untuk bisa lebih maksimal dan menggunakan metode yang sesuai dalam pengajaran. Metode kedua pengontrolan berkala yang dilakukan diluar hari pengajaran. Pengajaran dilakukan pada hari jumat, sedangkan pengontrolan berkala ditempatkan pada hari selasa dan kamis.

Mekanisme pengontrolan berkala yang dapat digunakan adalah dengan memutar video hasil siswa-siswi belajar pada saaat hari pengajaran dilaksanakan. Selanjutnya, mekanisme pengontrolan dapat dilanjutkan dengan terjun langsung ke lapangan dan melakukan sedikit pengetesan tentang materi yang telah diajarkan. Pengetesan secara langsung kepada siswa akan membuktikan apakah materi pembelajaran yang telah tim berikan benar-benar dapat diterima oleh seluruh siswa dan dapat diterapkan dengan baik.

\section{a) Lomba Berbasis Budaya}

Siswa-siswi SDLBN Kecamatan Balikapan Selatan dapat menerapkan program melalui kegiatan perlombaan berbasis budaya yang akan diselenggarakan oleh tim volunteer. Lomba berbasis budaya ini terbagi menjadi 3 kategori perlombaan berdasarkan pengelompokkan bidang minat mereka masing-masing. Dalam acara ini, tim volunteer akan mengundang pihak orangtua untuk ikut berpartisipasi didalam program ini. Hal ini bertujuan untuk lebih menambah keakraban antara orangtua, siswa, dan guru SDLBN Kecamatan Balikapan Selatan.

b) Evaluasi

Evaluasi dalam pemberdayaan siswasiswi SDLBN merupakan program pemantauan dengan melihat dari sejauh mana tingkat keberhasilan program dalam mengenalkan kearifan lokal dan budaya Indonesia kepada siswa-siswi SDLBN Kecamatan Balikapan Selatan. Hal ini dapat dilihat dari keseharian mereka baik didalam kelas maupun diluar kelas ketika bermain ataupun berlomba bersama teman-teman mereka. Adapun yang akan menjadi tolak ukur evaluasi ini yaitu dari tingkat kepercayaan diri anak-anak tunagrahita dalam bersosialisasi, serta kemampuan dalam mengaplikasikan program dalam kegiatan sehari-hari yang mereka lakukan.

\section{HASIL \& PEMBAHASAN}

Sekolah ini terletak di Jl. Syarifuddin Yoes Perumahan Balikpapan, Gunung Bahagia, Kecamatan Balikpapan Selatan, Kota Balikpapan seperti pada Gambar 1 Sekolah ini memiliki siswa seluruhnya 330 siswa yang terdiri dari 23 siswa TKLB, 173 siswa SDLB, 80 siswa SMPLB, dan 54 siswa SMALB (Data Primer, 2017).Kondisi para siswa terlihat sama seperti siswa normal pada umumnya ditunjukkan pada Gambar 3 hanya saja kemampuan daya pikir dan pertumbuhan yang mereka miliki kurang sempurna. Ada $10 \%$ dari siswanya bersatus autism, doublegrahita, dan tunarungu. Dalam proses pembelajaran, SLBN Kecamatan Balikpapan Selatan memiliki beberapa permasalahan. Permasalahan pertama, minimnya tenaga pengajar. Data terakhir di tahun 2017, jumlah pengajar sebanyak 18 guru yang memiliki latar belakang pendidikan berbeda-beda. Hal itu tidak sebanding dengan kondisi dan kebutuhan sekolah tersebut, baik dari segi tenaga pendidik maupun pelayanan tenaga pendidik. Padahal untuk sekolah formal biasa, dibutuhkan guru sebanyak lebih dari 50 guru untuk total keseluruhan siswa (Data Primer, 2017). 


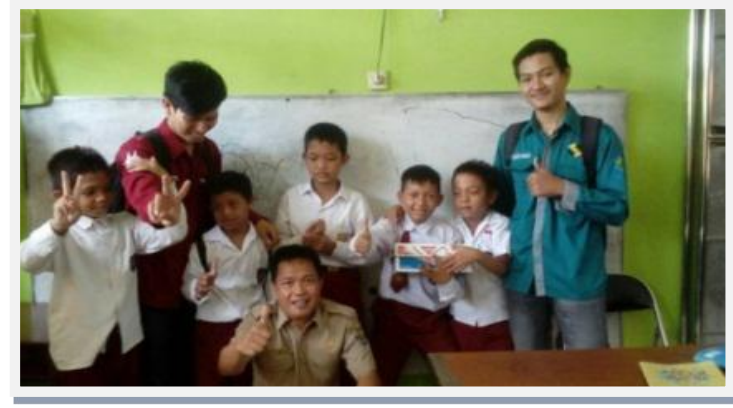

Gambar 3. Berinteraksi Dengan Siswa Tunagrahita

Pada SLB ini, jumlah siswa SD tunagrahita sebanyak 75 siswa dengan golongan tunagrahita $\mathrm{C} 1$ dan $\mathrm{C} 2$. Dalam proses pembelajaran di sekolah ini, memiliki kurikulum yang sama dengan sekolah biasa pada umumnya proses belajar mengajarnya pun tidak jauh berbeda. Di SLBN Kecamatan Balikpapan Selatan, guru menerangkan materi yang diajarkan. Setelah pemberian materi selesai, guru melakukan tanya jawab dengan murid sehingga murid lebih mampu untuk mengerti apa yang diajarkan. Guru juga dapat menggunakan alat peraga untuk beberapa pelajaran agar anak lebih tertarik untuk belajar dan mampu mengingat lebih baik materi pembelajarannya. Hanya saja, terdapat beberapa penambahan program untuk melatih keterampilan siswanya. Sehingga, mengharuskan satu orang guru untuk merangkap tugas dan mengampu beberapa pelajaran untuk memenuhi pelayanan yang diberikan.

Permasalahan kedua yaitu berkaitan dengan pembekalan seni dan kreativitas. Kurangnya tenaga pengajar kesenian menjadi penyebab permasalahan ini sehingga berakibat pada kurang adanya pengembangan kreativitas murid dalam bidang ini. Kemudian faktor keuangan khususnya untuk kesejahteraan guru sangatlah minim sehingga peminat tenaga pengajar untuk mengajar di SLBN Kecamatan Balikpapan Selatan masih kurang. Sehingga berdampak pula pada terbatasnya kegiatan ekstrakurikuler di SLB tersebut. Hal ini mengakibatkan siswa-siswi SLBN Kecamatan Balikpapan Selatan kekurangan wadah dalam menyalurkan dan mengembangkan kreativitasnya.

Berdasarkan skor IQ klasifikasi anak tunagrahita siswa SLBN Kecamatan Balikpapan Selatan memiliki dua karakteristik keperibadian. Pertama ada yang memiliki karakteristik mild yaitu siswa masih bisa dididik namun membutuhkan perhatian khusus, penyesuaian diri lebih rendah, memiliki sifat pemalu dan keterampilan yang dapat dilakukan tanpa selalu mendapatkan pengawasan khusus. Kemudian juga ada yang memiliki karakteristik moderate yaitu anak yang mampu dilatih, menampakkan kelainan fisik yang merupakan sebuah gejala bawaan serta adanya gangguan pada fungsi bicara.

Jika melihat kemampuan siswanya, sebagian sudah bersemangat untuk belajar dan berkreativitas dalam dunia kesenian. Hanya saja dukungan dan kedekatan orang tua terhadap anaknya masih kurang. Orang tua kurang dalam memperhatikan perkembangan anaknya saat di sekolah. Acara yang sering diadakan biasanya turut mengundang orang tua murid. Namun, banyak orang tua yang kurang peduli dan tidak hadir pada acara tersebut. Pada saat pengambilan rapor (hasil belajar siswa) mereka hanya datang untuk mengambil, tidak ada perbincangan dengan guru tentang perkembangan anaknya. Bahkan, kebanyakan orang tua tidak mengambil rapor anaknya dan dibiarkan saja tertumpuk di sekolah. Hal tersebut yang membuat kami memilih SDLBN sebagai sasaran dari program kami, salah satunya untuk mendekatkan hubungan orang tua dan anaknya di sekolah, sehingga perkembangan siswa SDLBN juga bisa dipantau oleh orang tua mereka.

Pada saat kegiatan program petama kali dilaksanakan, kegiatan berlangsung setelah diadakannya UAS Semester genap pada SLBN Balikpapan Selatan. Setelah diadakannya diskusi sesama tim volunteer, kegiatan program untuk hari pertama dilakukan pada hari Rabu, 23 Mei 2018 di salah satu ruang kelas. Sebelumnya dari pihak sekolah SLB telah menginfokan bahwa intensitas siswa-siswi SLB untuk datang ke sekolah ketika telah selesai UAS menjadi berkurang namun tim volunteer tetap mencoba untuk melakasanakan kegiatan ini karena keterbatasan waktu yang dimiliki oleh volunteer. Berikut pada Gambar 4 adalah kondisi saat hari pertama kegiatan program dilaksanakan.

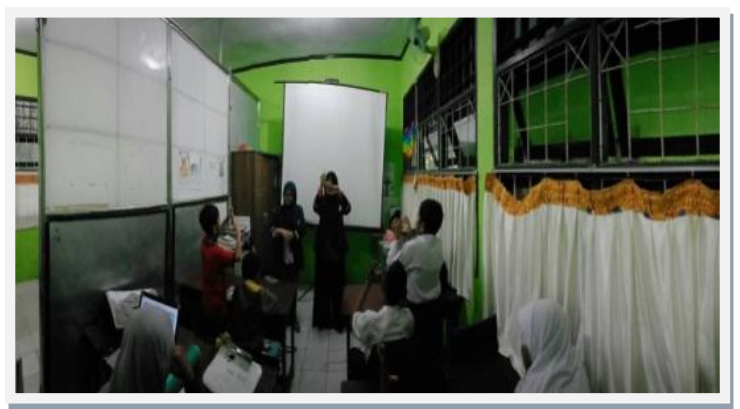

Gambar 4. Ice Breaking Dengan Siswa Tunagrahita 
Hanya ada 6 siswa yang datang ke sekolah untuk mengikuti kegiatan program dari 33 siswa yang di hubungi untuk bisa hadir ke sekolah. Siswa berasal dari kelas yang berbeda, namun kelas yang paling kecil tidak menutup kemungkinan bisa lebih baik menyerap materi yang telah disampaikan. Pada Gambar 5 berikut adalah saat tim volunteer mendampingi salah satu siswa tunagrahita.

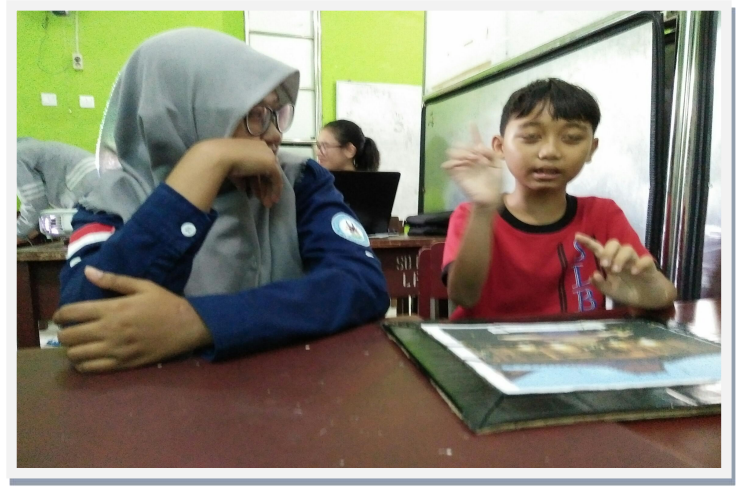

Gambar 5. Siswa Tunagrahita Bercerita

Selanjutnya dilakukan kegiatan simulasi seperti Gambar 6 pada hari Jum'at, 25 Mei 2018 dengan mengajak serta mengundang orangtua siswa SLB Balikpapan Selatan untuk dapat mendampingi anaknya mengikuti kegiatan program selain itu beberapa guru juga diikutsertakan dalam kegiatan ini. Hal ini dikarenakan salah satu faktor kunci yang dibutuhkan seorang anak berkebutuhan khusus yaitu kecukupan dukungan sosialnya dimana dukungan sosial dapat diterima secara langsung melalui orang tuanya, namun secara umum ditemukan berbanding terbalik seperti yang diharapkan (Gray \& Holden, 1992; White \& Hastings, 2004)

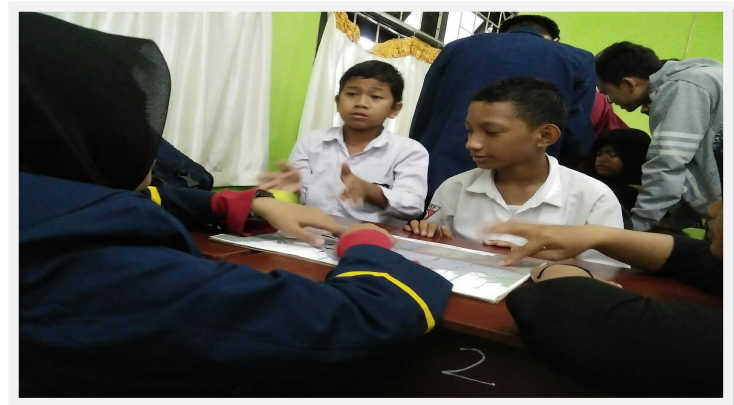

Gambar 6. Simulasi Dengan Pendampingan oleh Volunteer

Pada kegiatan simulasi, siswa-siswi yang hadir untuk mengikuti kegiatan program lebih banyak dari sebelumnya, hal ini karena kerjasama tim volunteer dengan pihak guru untuk bisa memaksimalkan siswa agar dapat hadir pada kegiatan ini. Kegiatan simulasi ini dilakukan di gedung serbaguna SLBN Balikpapan Selatan. Sebelum melakukan penyusunan puzzle, siswa-siswi diajak untuk bernyayi beberapa lagu tradisional agar menambah semangat dan meningkatkan sistem motorik dari siswa tunagrahita. Selanjutnya akan diperlihatkan gambar asli dari puzzle dan dijelaskan asal daerah dari gambar tersebut. Dijelaskan pula ciri khas dari gambar program tersebut. Masing-masing volunteer memiliki beberapa anak untuk didampingi agar materi dan penjelasan yang disampaikan dapat diulangi kembali oleh volunteer kepada siswa tunagrahita agar dapat meningkatkan daya ingat siswa tunagrahita. Selanjutnya siswa mulai menyusun puzzle yang telah dibongkar oleh volunteer dan menyusunnya kembali seperti gambar di awal. Setelah semua kegiatan telah dilaksanakan, selanjutnya semua peserta yang hadir berfoto bersama seperti pada Gambar 7 berikut.

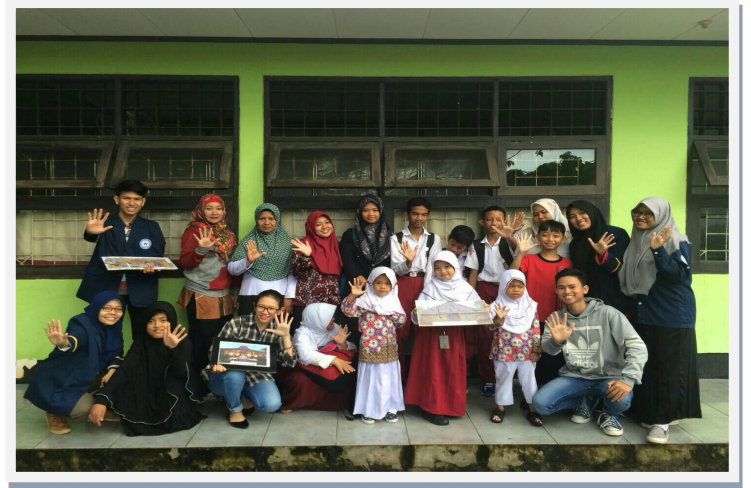

Gambar 7. Foto Bersama Setelah

Pelaksanaan Program

Berdasarkan hasil observasi setelah melakukan kegiatan selama dua kali dengan selingan waktu materi dan simulasi bertujuan agar siswa tunagrahita tidak merasakan bosan dan jenuh. Dikarenakan pada saat melakukan simulasi siswa tunagrahita bertambah dan terdapat beberapa siswa yang belum mendapatkan materi awal, sehingga pengulangan pemberian materi pun dilakukan. Dan terbukti siswa yang telah mendapatkan materi di pertemuan sebelumnya cepat menangkap materi yang diberikan, namun siswa tunagrahita yang belum mendapatkan materi sebelumnya harus dilakukan pengulangan hingga beberapa kali oleh masing-masing volunteer yang mendampingi.

Setelah dilaksanakan simulasi di pertemuan berikutnya dilakukan lomba berbasis budaya, dimana siswa-siswi tunagrahita diajak untuk mengaplikasikan semua materi yang didapatkan mulai dari rancang bangun bangunan tradisional dengan 
bermain puzzle bergambar rumah tradisonal seperti Gambar 8, pengetahuan akan musik tradisional dengan bernyanyi bersama seperti Gambar 9 , dan permainan tradisional yaitu bermain ular naga dan dakon bersama seperti Gambar 10. Berdasarkan hasil observasi yang dilakukan semua siswa tunagrahita sangat gembira dan dapat melaksanakan program secara maksimal.

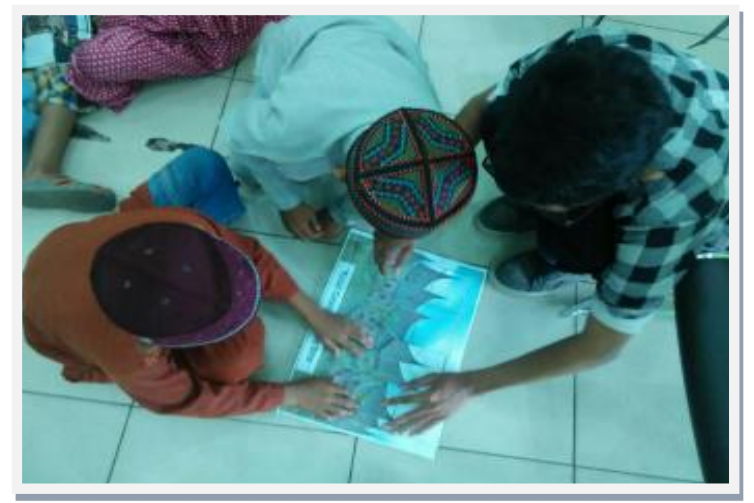

Gambar 8. Pendampingan Oleh Salah Satu Volunteer Pada Saat Lomba Berbasis Budaya

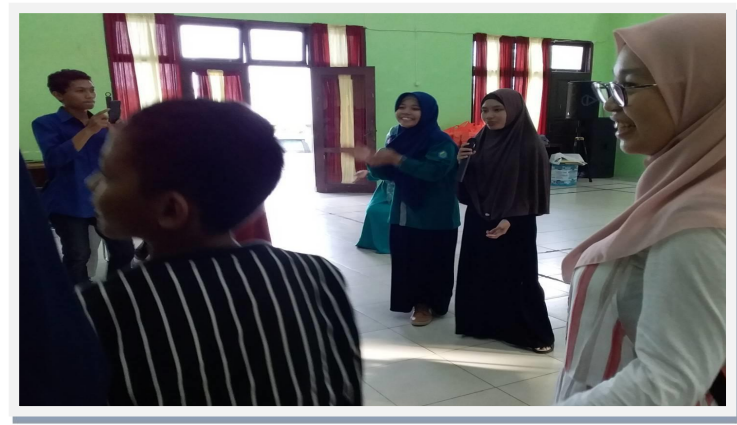

Gambar 9. Volunteer Dan Siswa Sedang Menyanyikan Lagu Daerah

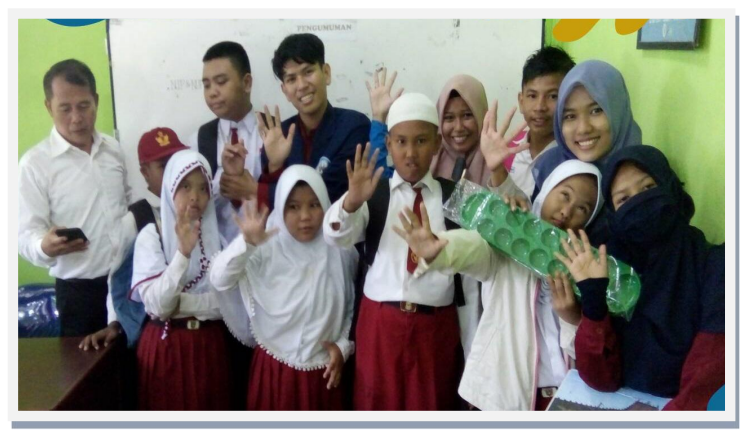

Gambar 10. Foto Bersama Setelah Bermain Permainan Tradisional

Berdasarkan hasil observasi dan penilaian dari jurnal penilaian yang dilakukan volunteer dengan objek penilaian sebanyak 23 orang siswa tunagrahita dan skala penilaian sangat baik (8-10), baik (6-7), cukup (5), kurang (3-5), dan sangat kurang (di bawah 3), yang digambarkan dalam grafik seperti pada Gambar 11 berikut ini

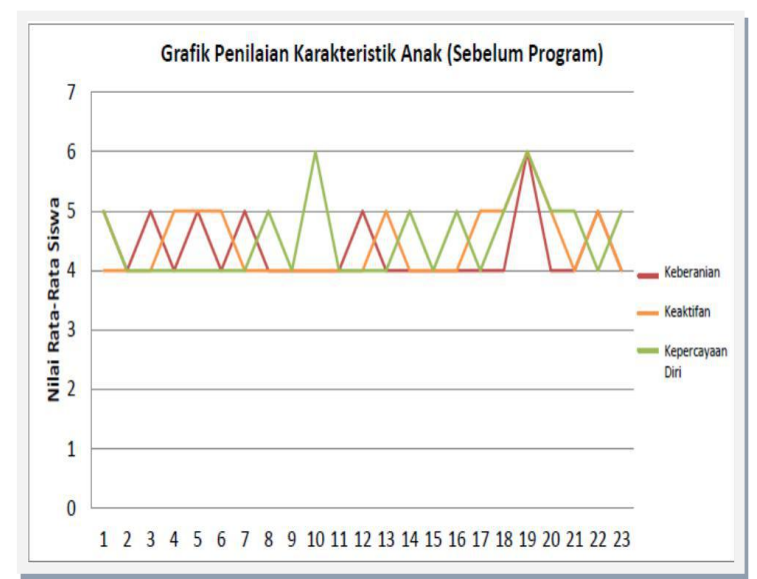

Gambar 11. Grafik Penilaian Karakteristik Anak Sebelum Pelaksanaan Program

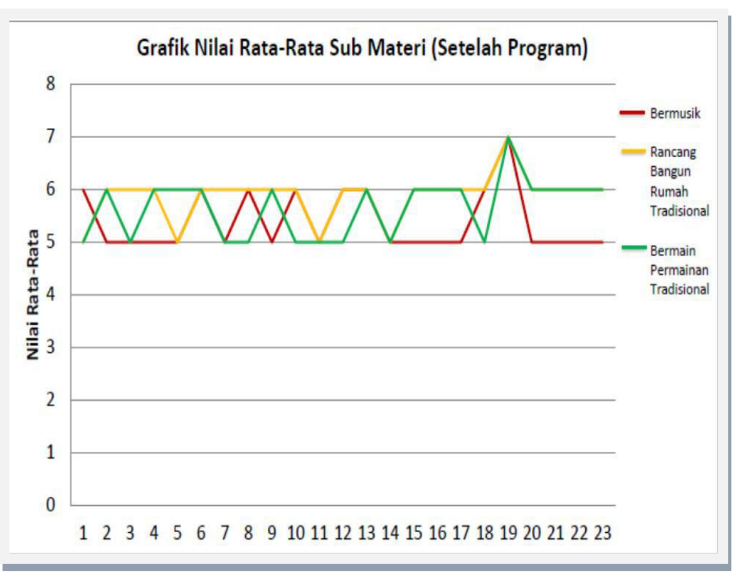

Gambar 12. Grafik Nilai Rata-Rata Penguasaan Materi Pada Anak Tunagrahita

Dari grafik di atas terlihat bahwa rata-rata pengetahuan siswa tunagrahita sebelum dilaksanakannya program ini berada pada interval kategori "cukup" yang dinilai melalui aspek penilaian keberanian, keaktifan, dan kepercayaan diri siswa tunagrahita. Kemudian, penguasaan materi siswa tunagrahita mengalami peningkatan dengan rata-rata pada kategori "baik" setelah dilaksanakannya program melalui pengimplementasian materi bermusik, rancang bangun rumah tradisional, dan bermain permainan tradisional dengan aspek penilaian yang sama seperti pada Gambar 12. Sehingga dapat disimpulkan bahwa metode pembelajaran bermain sambil belajar budaya bagi siswa tunagrahita di SDLBN Kecamatan Balikpapan Selatan untuk mengenalkan kearifan lokal dan budaya Indonesia sejak usia dini berhasil dilaksanakan melalui pengabdian masyarakat ini. 

satu solusi alternatif dalam mengenalkan budaya dan kearifan lokal Indonesia sejak usia dini pada siswa tunagrahita di SDLBN Kecamatan Balikpapan Selatan melalui metode bermain sambil belajar budaya dengan pendekatan yang inovatif yang diberikan dan juga merupakan hal baru yang dapat membantu pihak sekolah dalam memberikan materi pengajaran di kelas. Program bermain sambil belajar budaya ini dapat menjadi contoh pembelajaran bagi sekolah luar biasa lain di Balikpapan khususnya maupun di Indonesia pada umumnya.

\section{DAFTAR PUSTAKA}

Fithriyani, Azmi Sita. (2015). Perkembangan Kongnitif dan Psikomotorik Anak Tunagrahita (Studi Pada Keterampilan Tata Boga Di SLB Negeri Pembina Yogyakarta). Yogyakarta: UIN Sunan Kalijaga. Diakses dari http://digilib.uinsuka.ac.id/18220/1/11250023 bab-i ivatau-v_daftar-pustaka.pdf

Gray, DE., Holden, WJ. (1992). Psycho-social well-being among the parents of children with autism. Journal of Intellectual and Developmental Disability. 18. 83-93. Diakses dari https://www.tandfonline.com/doi/abs/10.1 080/07263869200034841

Oedjoe, MR., Beatriks, N. (2016). Meningkatkan Kemampuan Motorik Kasar melalui Permainan Tradisional "SIKODOKA" Bagi Anak Usia Dini Berlatar Belakang Tuna Grahita. Jurnal Ilmiah VISI PPTK PAUDNI. 11. 73-80. Diakses http://journal.unj.ac.id/unj/index.php/jiv/a rticle/view/3655

Odom, SL., Wolery, M. (2003). A unified theory practice in early intervention/early childhood special education: Evidence based practices. The Journal of Special Education. 37. 164-173. Diakses dari http://journals.sagepub.com/doi/abs/10.11 77/00224669030370030601

White, N., Hastings, RP. (2004). Social and professional support for parents of adolescents with severe intellectual disabilities, Journal of Applied Research in Intellectual Disabilities. 17. 181-190. Diakses dari https://onlinelibrary.wiley.com/doi/abs/10. 1111/j.1468-3148.2004.00197.x 